\title{
Landscape analysis of the family planning situation in Pakistan-District profile: Hyderabad
}

Population Council

Follow this and additional works at: https://knowledgecommons.popcouncil.org/departments_sbsr-rh

Part of the Demography, Population, and Ecology Commons, Family, Life Course, and Society Commons, and the International Public Health Commons How does access to this work benefit you? Let us know!

\section{Recommended Citation}

"Landscape analysis of the family planning situation in Pakistan-District profile: Hyderabad." Islamabad: Population Council, 2016. 


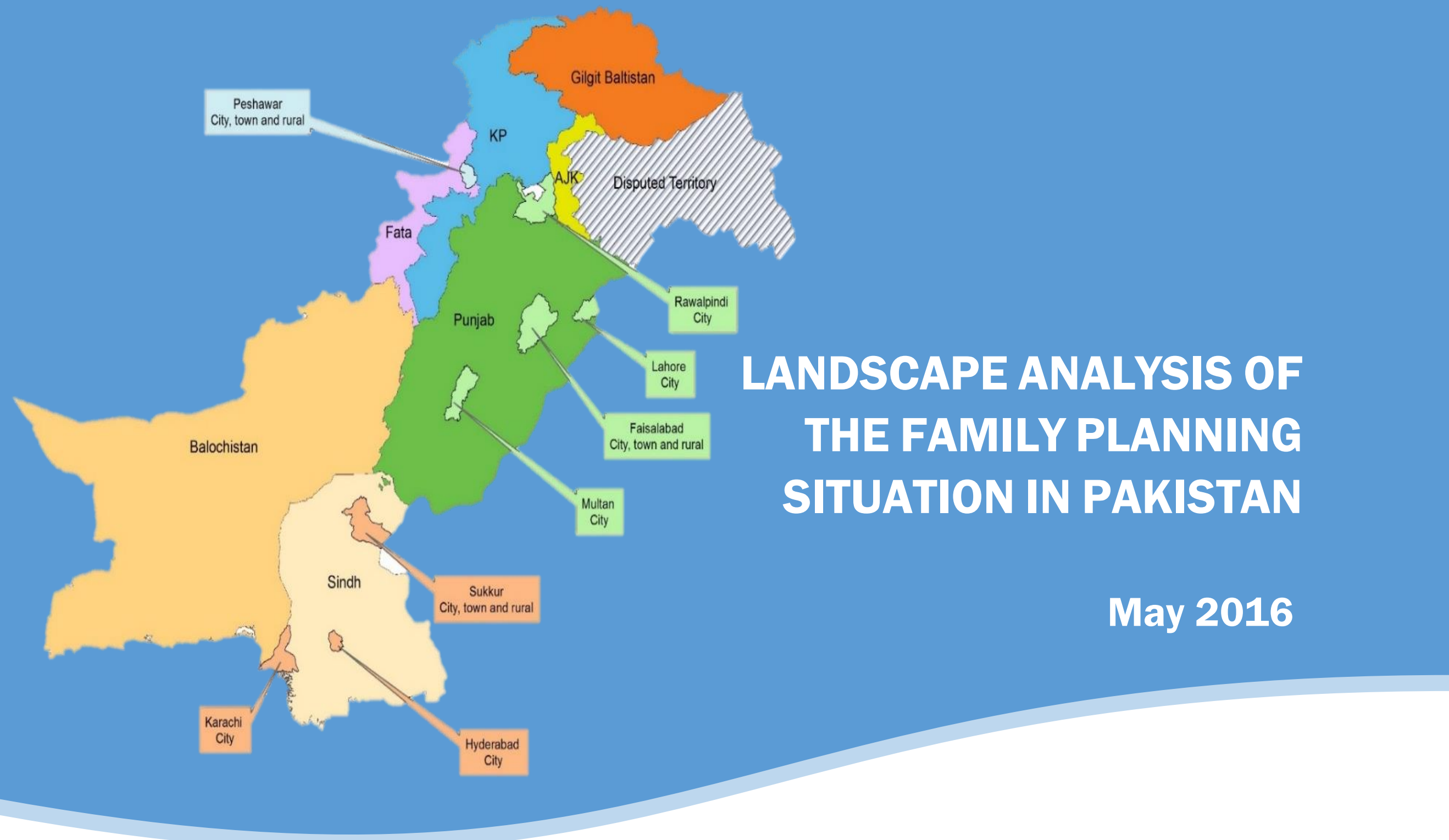

\section{DISTRICT PROFILE: HYDERABAD}

BILL MELINDA

GATES foundation 


\section{Background}

Hyderabad is situated in the southern part of the province of Sindh. It has an estimated population of 2.2 million. ${ }^{1}$ The district consists of four administrative divisions (talukas), including Hyderabad, Hyderabad City, Qasimabad, and Latifabad (Figure 1).

Table 1 presents key demographic facts about the district. The majority of the population (85\%) resides in urban areas. Of the estimated 0.35 million married women of reproductive age (MWRA) in the district, 0.29 million live in urban areas. The numbers of women of reproductive ages are higher in urban areas but the proportion of married women of reproductive age (MWRA) is higher in rural than urban areas.

Hyderabad's total fertility rate (TFR), at 3.0, is much lower than Sindh's average TFR of 4.0 (MICS 2014). The district's infant mortality rate (IMR) is 85 .

Table 1: Demographics of Hyderabad

\begin{tabular}{|c|c|c|c|}
\hline Demographics & Urban & Rural & Overall \\
\hline Total population & $1,880,000$ & 312,000 & $2,192,000$ \\
\hline Women 15-49 & 480,000 & 70,000 & 550,000 \\
\hline MWRA & 292,000 & 53,000 & 345,000 \\
\hline $\begin{array}{l}\text { Literacy rate (10 } \\
\text { years and above)* }\end{array}$ & $64 \%$ & $35 \%$ & $59 \%$ \\
\hline $\mathrm{IMR}^{* *}$ & - & - & 85 \\
\hline TFR** & - & - & 3.0 \\
\hline \multicolumn{4}{|c|}{$\begin{array}{l}\text { Source: Sindh Development Statistics 2013, * Pakistan Social and Living } \\
\text { Standards Measurement Survey (PSLMS) 2014-15, **Multiple Indicator } \\
\text { Cluster Survey Sindh } 2014\end{array}$} \\
\hline
\end{tabular}

1 Estimate based on Sindh Development Statistics 2013.
Figure 1: Map of Hyderabad District

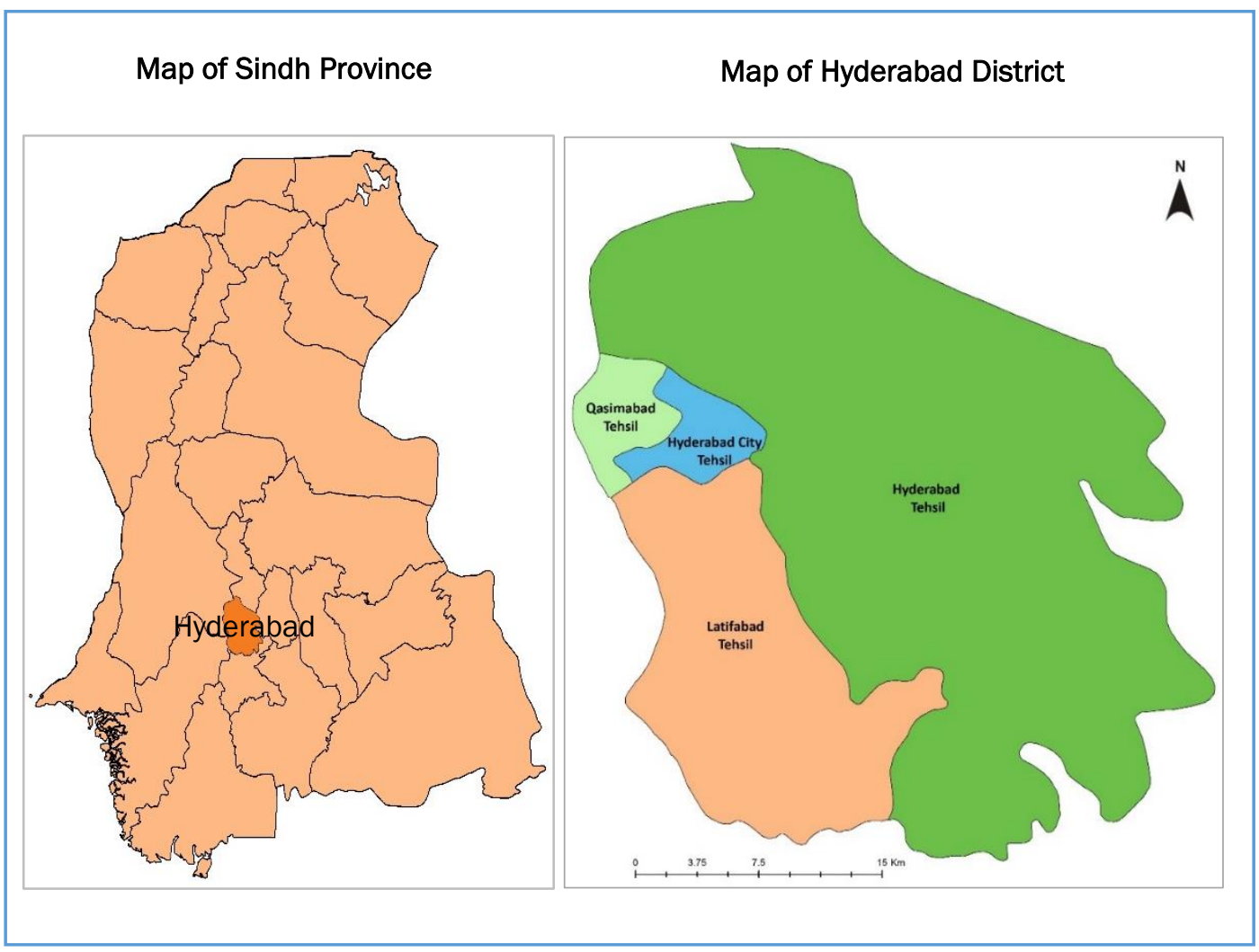

\section{Use of Antenatal and Delivery Care Services}

The majority of women in Hyderabad (86\%) sought antenatal healthcare from a skilled provider during their last pregnancy, ${ }^{2}$ but their proportion was much higher in urban (92\%) than in rural areas (60\%). Both in urban and rural areas, private hospitals or clinics comprise the major source of antenatal healthcare. The most common places of delivery in urban areas are, again, private hospitals or clinics (61\%), but in rural areas, almost half of all deliveries take place at homes.

2 Pakistan Social and Living Standards Measurement Survey (PSLMS) 2014-15 


\section{Use of Family Planning}

The contraceptive prevalence rate in Hyderabad is 33.3 percent, ${ }^{3}$ which is higher than the average for Sindh (29\%). Users mainly prefer modern methods, with only 4.4 percent currently using traditional methods (Table 2). Unmet need for contraception in Hyderabad is 17.5 percent, which is lower than Sindh's average of 21.7 percent.

Table 2: Contraceptive Use and Unmet Need

\begin{tabular}{lcccc}
\hline & \multicolumn{2}{c}{ Contraceptive Prevalence Rate (CPR) } & \\
\cline { 2 - 4 } District & $\begin{array}{c}\text { Any } \\
\text { Method }\end{array}$ & Traditional Methods & $\begin{array}{c}\text { Modern } \\
\text { Methods }\end{array}$ & $\begin{array}{c}\text { Unmet } \\
\text { Need }\end{array}$ \\
\hline Hyderabad & 33.3 & 4.4 & 28.9 & 17.5 \\
\hline
\end{tabular}

Source: Multiple Indicator Cluster Survey (MICS), Sindh, 2014

\section{Other Socio-economic Indicators}

While the overall literacy rate (10 years and above) in Hyderabad is 59 percent, the urban rate $(64 \%)$ is almost double that in rural areas (35\%). Female literacy is lower, especially in rural areas (24\%).

The majority of households own a television set (85\%), but urban-rural differences are huge, with 92 percent of urban households owning a TV set, compared to only 51 percent of rural households. Mobile or landline phones are owned by the vast majority of households (93\%).

Most of the houses in urban areas have reinforcement of brick and cement (RCC) or reinforcement of concrete and cement (RBC) roofs $(67 \%)$, indicating higher socio economic status in contrast to the rural areas, where the majority use cheaper wood or bamboo $(52 \%)$, followed by garder (iron slabs)/T-Iron (43\%). Both in urban and rural areas, burnt bricks or blocks are mainly used for the house walls. This indicates better socio-economic status

\section{Consumer Perspectives on Barriers to Use of Family} Planning

During the landscape assessment, perspectives of men and women on family planning use were collected in the main city through two focus group discussions, one each with men and women. A total 19 men and women participated in discussions from this study district, and were asked about the barriers they encounter in using family planning services.

Based on respondents' views, two barriers to use of family planning were identified, including lack of information and services for family planning among men; and low accessibility to public facilities, a problem for poorer families.

Lack of information among men

- Men feel embarrassed and reluctant talking about family planning and consider it inappropriate to discuss such personal matters with other men.

"You can discuss almost all matters with friends except this because this issue can be discussed at home privately." Male, Hyderabad city

- Men want to dispel their hesitation and want detailed information on family planning methods but through knowledgeable person such as doctors.

"There is lack of knowledge about family planning. There should be discussions about family planning so that people don't feel any hesitation about discussing it. Mostly we do not value what we listen from each other thus doctors should brief us when we go for checkups." Male, Hyderabad city

Limited access to public health facilities compounded by poverty -a hurdle for urban poor

- At public hospitals, service providers usually attend clients who are government employees; non- employees are left with no choice except going to private sector but it is hard to afford travel and service cost especially for poor.

"There is a public dispensary in the area that attends to only government employees. Poor non-employees can not avail this facility". Male, Hyderabad city

"There is a private hospital in Latif Abad and it cost us 300 rupees for the round trip". Female, Hyderabad city

- Limited timings also discourage men and women to go to far away public health facilities

"The Govt hospitals close after 2PM. It takes us half day to reach there if we want to seek services from there. This is why we are very upset. People can only go to private hospitals if they have money." Male, Hyderabad city. 


\section{District specific Donors, Projects and Implementing partners}

\begin{tabular}{|c|c|c|}
\hline Donor & Program/ Project Title & Implementing Partner \\
\hline \multirow{2}{*}{$\begin{array}{l}\text { Bill and Melinda } \\
\text { Gates Foundation }\end{array}$} & $\begin{array}{l}\text { Building Blocks for Family Planning in Pakistan - Developing a Costed } \\
\text { Implementation Plan for Sindh and Punjab, 2013-2015 }\end{array}$ & Pathfinder International \\
\hline & Landscape Analysis of the Family Planning Situation in Pakistan, 2015-2016 & Population Council \\
\hline \multirow{2}{*}{$\begin{array}{l}\text { The David \& Lucile } \\
\text { Packard Foundation }\end{array}$} & $\begin{array}{l}\text { Increasing Access and Use of Contraceptives in Punjab/Sindh: Keeping } \\
\text { Momentum \& Innovating for Success, 2012-2015 }\end{array}$ & DKT Inc. \\
\hline & Achieving MDG5 - Continuing Momentum, Building Champions, 2012-2015 & Shirkat Gah Women Resource Centre \\
\hline \multirow[t]{4}{*}{ USAID } & DELIVER Project, 2008-2016 & $\begin{array}{l}\text { Planning Commission of Pakistan } \\
\text { Ministry of Health }(\mathrm{MOH}) \\
\text { Provincial and regional departments of Health and } \\
\text { Population } \\
\text { UNFPA } \\
\text { NGOs }\end{array}$ \\
\hline & Family Planning and Reproductive Health Services, 2013-2017 & Marie Stopes Society \\
\hline & Health Communication, 2014-2019 & JHUCCP \\
\hline & Health System Strengthening & JSI Research \& Training Institute, Inc. \\
\hline \multirow[b]{2}{*}{ UNFPA } & $\begin{array}{l}\text { Capacity Building of Female Service Providers Enhanced in Family Planning, } \\
2014-2017\end{array}$ & $\begin{array}{l}\text { Population Welfare Departments } \\
\text { MNCH Programs } \\
\text { LHWs Program }\end{array}$ \\
\hline & $\begin{array}{l}\text { Advocacy for Universal Access to Reproductive Health and to Integrate in } \\
\text { Provincial Health Policies, Plans and Budgetary Frameworks, 2012-2017 }\end{array}$ & $\begin{array}{l}\text { Population Welfare Departments } \\
\text { Population Council } \\
\text { Pathfinder } \\
\text { Ministry of National Health Services, Regulations and } \\
\text { Coordination }\end{array}$ \\
\hline WHO & $\begin{array}{l}\text { Technical Assistance for Development of a Unified Care Providers' Manual } \\
\text { based on the WHO Handbook on FP }\end{array}$ & $\begin{array}{l}\text { Ministry of National Health Services Coordination and } \\
\text { Regulation } \\
\text { MNCH programs } \\
\text { UNFPA, Population Council, GIZ, USAID, etc. }\end{array}$ \\
\hline $\begin{array}{l}\text { Large Anonymous } \\
\text { Donor (LAD) }\end{array}$ & $\begin{array}{l}\text { Increasing Access to and Use of Long Term Methods of FP and PAC Services } \\
\text { in Pakistan, 2014-16 }\end{array}$ & Greenstar Social Marketing \\
\hline
\end{tabular}

